\title{
Professional Competition in Global Tax Reform: Transparency in Global Wealth Chains ${ }^{1}$
}

Rasmus Corlin Christensen, Copenhagen Business School, rcc.dbp@cbs.dk

DRAFT VERSION, MAY 2017. ALL COMMENTS WELCOME.

\begin{abstract}
In the wake of the Great Recession, international corporate taxation has risen to the top of the global political agenda. With states seeking to shore up national fiscal systems, the OECD/G20 Base Erosion and Profit Shifting (BEPS) project has emerged as the key response in this regard. Among 15 action points, Action 13 on corporate tax transparency has been particularly prominent. By shaping the feasibility of corporate tax strategies and the information resources available to national tax authorities, the Action 13 policy recommendations will fundamentally reconfigure the context of corporate tax behaviour and global wealth chains, i.e. strategies and structures for wealth creation and protection in the global economy. How did these new critical rules come about? Unfortunately, little is known about the micro-level process, dynamics and actors of the BEPS project. This paper provides an original case study of the changing international tax system and the regulatory context of global wealth chains, based on an investigation of the professionals engaged in global tax reform. Drawing on observations, interviews and sequence analysis of professional careers, it studies the dynamics of the professional policy environment and identifies distinct career and knowledge trends. The paper shows that professional competition for prestige and knowledge played a central role in the complex, transnational policy process. Operating within a technical policy environment, far removed from high-level politics, professionals seeking to make their mark on new standards for corporate tax transparency mobilised expertise and network capital, shaping what could be discussed, the criteria for accepted arguments, and who was listened to in the policy process, thus critically affecting the final policy outcomes.
\end{abstract}

Keywords: Transparency, BEPS, professionals, competition, tax, global wealth chains, expertise, networks.

\footnotetext{
${ }^{1}$ Thanks go to Duncan Wigan and Leonard Seabrooke for thoughtful comments on earlier versions of this paper. I have also received valuable feedback from participants at seminars at Copenhagen Business School, University of Bergen, Alliance Manchester Business School and Université Libre de Bruxelles.
} 


\section{Introduction}

Opaque corporate structures and tax practices are key enablers of cross-border profit shifting. Following the financial crisis, with many states facing slow growth and large deficits, governments have called for international action to shore up corporate tax systems. The G2O/OECD Base Erosion and Profit Shifting (BEPS) project is the key response in this regard. BEPS aims at far-reaching policy change on international tax laws, tax mismatches and corporate tax transparency. BEPS combines strong political backing from the G20 with the OECD machinery's technical expertise and ability to create and diffuse soft law tax outputs. While international corporate taxation is highly technical, it is also highly political, with major impacts on national and global economies. The rules developed through BEPS will have wide-ranging economic, normative and political consequences, including changes to the regulatory context of Global Wealth Chains (GWC), "transacted forms of capital operating multi-jurisdictionally for wealth creation and protection" (Seabrooke and Wigan, 2017). The BEPS project will re-define what is permissible within chains, as well as reconfigure fundamentals of the international tax system and corporate tax behaviour.

With so much at stake, it begs the question of how these rules emerge. What is the micro-level environment in which new global rules are developed? Unfortunately, political science scholars have paid surprisingly little attention to micro-level environments and actors in international tax reform, with very little systematic work on these aspects of BEPS and previous international tax reforms. Recent work on the role of professional environments and experts in global governance has focused on areas such as accountancy governance (Botzem, 2008; 2012), banking regulation (Lall, 2012; Young, 2012), financial reform (Baker, 2010; Seabrooke \& Tsingou, 2014) and transnational lawmaking (Trubek et al. 1994; Quack, 2007).

This paper builds on these works but also complements them in important ways, empirically and theoretically. Empirically, it contributes an original case study on international tax reform and 
the professional environment that produces rules underpinning GWCs and the international tax system. It does so through a micro-level analysis of professionals and knowledge in one particularly prominent item in BEPS, namely Action 13 regarding transfer pricing documentation (TPD) and country-by-country reporting (CBCR). Transfer pricing (TP), the pricing of intra-firm (or relatedparty) transactions, is a central reform point in relation to GWCs. The application of TP is key to GWCs in the allocation of wealth through integrated multinational corporate operations and the potential obfuscation (legal and illegal) of corporate tax duties (Sikka \& Willmott, 2010) ${ }^{2}$. Of particular significance is the BEPS Action 13 debate around CBCR. CBCR will require disclosure by MNCs of taxes and economic activity indicators for each jurisdiction in which they operate. Long pursued by groups critical of the current international tax system, the discussion and policy outcomes related to CBCR may lay the foundation for a move away from established standards in $\mathrm{TP}$ and international taxation ${ }^{3}$, and even towards an alternative system of unitary taxation ${ }^{4}$, which would revolutionise wealth chains by removing, or greatly altering, incentives for cross-border profit shifting (Clausing \& Avi-Yonah, 2007:14). The case study on BEPS Action 13 is based on evidence from extensive fieldwork, interviews and direct and participant observation in the international tax and transfer pricing communities in 2014-16, as well as sequence analysis of the CVs of the professionals involved.

Theoretically, the paper offers a novel conception of regulatory environments, based on the notion of professional competition, and expands on existing work on Global Wealth Chains by adding an analysis of professional interactions in shaping GWC policy environments. 'Professional competition' is an interactive process within and between groups of professionals that shape the

\footnotetext{
${ }^{2}$ By some estimates, transfer mispricing is the mechanism behind 70\% of all capital flight (Palan et al., 2010:68).

${ }^{3}$ This includes the separate entity principle, whereby MNCs are treated, in law, as networks of unaffiliated entities, rather than coherent groups.

${ }^{4}$ Under unitary taxation, the MNC is treated as one group for tax purposes, with national taxes based on a single profit pool and allocated according to a pre-determined formula of economic activity indicators, such as sales or headcount or a combination thereof, rather than internally allocated on notional market terms (Clausing \& Avi-Yonah, 2007).
} 
professional environment in which policy emerges, including how policy knowledge and professionals themselves are perceived. As certain combinations of expertise, networks and knowledge provide professionals with benefits, such as prestige and influence, within a given professional field or policy area, these characteristics become prominent and sought after in the professional environment. This competition plays a central yet underestimated role in complex, transnational policy processes, such as BEPS Action 13. Highly technical yet political policy discussions are contingent upon expertise (being able to speak authoritatively) and networks (being listened to). The paper argues that professional competition fundamentally affects policy processes through actor's attempts at obtaining, applying and leveraging expertise and networks. Groups of professionals impacting international tax reform processes seek prestige and authority by building and utilising key connections, gaining brokerage skills, and leveraging knowledge, including by going through 'revolving doors', i.e. moving strategically between sectors and work roles throughout their career. In particular, the paper discusses two types of professionals important in conditioning international tax policy processes: professionals that are primarily characterised by a broad, relevant expertise base across professional fields (termed "octopuses") and professionals primarily characterised by strong network positioning in specific professional areas ("arrows").

The paper is structured as follows. Section 1 details the theoretical approach and relates it to relevant literature on global wealth chains and International Political Economy (IPE). Section 2 outlines the methods and data applied, in particular the combination of observation, interviews and sequence analysis. Given that sequence analysis is a method largely unfamiliar to global political economy studies (cf. Seabrooke and Nilsson, 2015), I explain the basics of the method in detail. In section 3, I situate BEPS Action 13 in the historical context of international tax reform and corporate tax transparency, discussing the policy process and impact on GWCs. In section 4, I provide the main analysis of professional competition in BEPS Action 13, highlighting the importance of revolving 
doors, "octopus" and "arrow" professionals, and "lobby centres" as factors shaping international tax reform. In section 5, I discuss the results and implications for future research.

\section{Professionals in Transnational Governance}

This paper applies a micro-level theoretical approach focused on professionals, building on but expanding existing work on transnational governance within IPE. I draw on and contribute to the 'transnational professionals' research stream, which emphasises changing patterns of authority and recognises the importance of professional knowledge in shaping global political economy environments, which are populated by various technical experts. In doing so, the analysis recognises but seeks to complement previous IPE literature on international tax reform, which has largely focused on the macro role of state interests.

Within the global political architecture, I argue that the study of the practical micro-level political environments offers important insights into transnational policy processes and reform of the international corporate tax system. This complements existing IPE work on international taxation, which has emphasised the importance of nation-states battling for political outcomes based on national competitiveness concerns, thus shaping international tax competition and reform (Rixen 2010, 2013; Gentschel and Seelkopf, 2015). However, we can understand transnational professionals as actors 'beyond the nation-state' (Haas, 1992; Djelic and Quack 2010), which have leeway in mobilising to and engaging with global policy processes separated from the confines of entrenched domestic institutions and politics (Seabrooke 2014). Transnational professional competition is detached from national spaces and requires diverse knowledge and connections to address highly technical issues, providing a unique opportunity for mobile professionals to engage (Faulconbridge \& Muzio, 2011). It offers professionals the chance to reconfigure "how they work rather than replicating their national institutions or changing their own to reflect other national institutions" 
(Seabrooke 2014:55). In the delegation of technical problem solving, states afford professionals at the micro-level a certain autonomy (Barnett \& Finnemore, 2004). In relation to OECD tax policy development specifically, the role of policy interactions between technical experts across nations and organisational boundaries has been particularly crucial and fruitful (Salzman, 2005; Woodward, 2009; Christians, 2010). Within BEPS, the OECD framework and policy environment have meant professionals have played a significant role in developing the technical policy outcomes from a political starting point. As one high-ranking OECD official emphasised, the high-level political direction was set by G-20 states, but the "important technical details are to be worked out in the BEPS process" (author's interview). In short, while nation-states were important in pushing issues onto the agenda and defining boundaries of the BEPS project, the interactions of professionals have been highly impactful for policy environment and the policy outcomes.

This micro-level professional focus also extends previous work on Global Wealth Chains. The GWC framework draws on political science, organization studies and institutional economics in highlighting the production and maintaining of wealth chains and their regulatory contexts, including the importance of professional dynamics. Thus, early GWC scholarship has specifically invited studies on "how global wealth chains are articulated, including locating what kinds of actors and organizations are involved and what kind of processes permit their existence" (Seabrooke \& Wigan 2014:28). This paper adds methods from economic sociology to the GWC toolkit and applies them in addressing the professional interactions and policy environments that condition GWC regulatory contexts.

Previous micro-level IPE work on international tax and GWC governance can be divided under three headings: regulatory capture, international bureaucrats and transnational professionals. Regulatory capture stories have argued that business or class elites 'capture' regulatory processes to define legislation in their interest, in essence overruling states and grand structures. Post-crisis, 
regulatory capture was prominently blamed for lax regulation and the financial meltdown (e.g. Baker, 2010; Lall, 2012). Within the international tax literature, Hampton \& Christensen have argued that the emergence of offshore tax havens was facilitated by elite lawyers (2011:172), and Webb (2004) has argued that OECD's early-200s "Harmful Tax Competition" (HTC) project, a crackdown on offshore tax havens, was blunted by capture by transnational taxpayers and private-sector tax experts.

The 'international bureaucracies' literature has provided useful accounts of the role of international organisation (IO) staff in international tax governance, including the OECD. This scholarship has emphasised the bureaucratic culture of IOs and the resulting authority and autonomy of staffers, as well as 'pathologies' that flow from this (Barnett \& Finnemore, 1999; 2004). Woodward (2009) and Sharman (2012) locate the success of OECD staffers in creating and diffusing global tax policy outputs in shared bureaucratic culture; Sharman specifically notes the OECD bureaucrats' "shared rationalising vocation, ordering, categorising and recording economic activity" (2012:24-25). Furthermore, Morris and Mobert (2012) and Porter and Webb (2007) suggest that the liberal economic culture among OECD staffers structures the organisation's policy outputs, while Eccleston \& Woodward (2014) argue that the OECD's bureaucratic nature have led to a weak, 'lowest common denominator' standard within information exchange of tax information.

While these analyses provide valuable input on the micro-level professional environments of international tax reform, there is scope for a complementary account emphasising professional agency itself in the interactive processes and dynamics in tax policy environments. Though 'regulatory capture' and 'IO bureaucracy' analyses are largely micro-level stories, the explanatory power essentially remains at the macro level. The regulatory capture logic holds that elites are structurally privileged agents, afforded a priori power in the policy environment, while the IO bureaucracy logic holds that IO staff practices and pathologies, and consequent policy outcomes, are shaped by organisational culture. In both cases, professionals are viewed as a type of 'performing agents', 
reductions of macro-/meso-structural factors, leaving little room for micro-level agency and analytical weight (cf. Sending 2002). Furthermore, the two approaches set out from a conception of certain (groups of) actors as inherently authoritative and "insider" to policy-making power (respectively, elites and IO staff), leaving space for a complementary, 'open' micro-level approach that places the establishment or discovery of those boundaries, between "insiders" and "outsiders", between authorities and non-authorities, at the heart of the analysis.

Work on professionals in transnational governance has attempted to fill these spaces, and this paper aligns primarily with this literature. The transnational professionals literature builds on earlier work on 'epistemic communities' (Haas 1992) and regulatory delegation to private experts (Mattli \& Büthe, 2011), which showed the conditioning of political environments through transnational professional interactions. More recently, Seabrooke (2014) has conceptualised transnational professionals as unique actors engaged in professional competition in political environments. Professional interactions condition (political) institutions, including through the exercise of expertise and the reorganisation of hierarchies within organisational fields (Suddaby \& Viale, 2011; Muzio, Brock \& Suddaby, 2013). These dynamics are particularly central in the context of professional and political transnationalisation, whereby complex rule-making is becoming increasingly dispersed and removed from national spaces, with resourceful professionals playing central roles, engaging in cooperation and competition on knowledge, prestige and policy solutions (Fourcade, 2006; Quack, 2007; Seabrooke, 2014).

The 'transnational professionals' literature and its micro-level analysis of professional dynamics and competition, including their relation to political and knowledge environments, draws on the theoretical heritage of Andrew Abbott and Pierre Bourdieu, who both analysed traditional professional groups in terms of competition, conceiving professionals as engaged in meaningful interactive processes of organization, institution-building and politics. The analysis of Bourdieu 
(1986, 1993) and followers (e.g. Dezalay \& Garth, 1995; Dezalay \& Sugarman, 1995) emphasised professional power and class dynamics of dominance and subordinate, whereas Abbott's $(1995,2005)$ analysis, alongside successors (e.g. Seabrooke \& Tsingou 2009; Seabrooke 2014), focused on a more 'symbiotic' competition for professional jurisdictions across flexible 'ecologies'. However, both Abbott and Bourdieu viewed groups of professionals as united by bodies of esoteric knowledge and procedures, struggling against other groups for various benefits. They also both recognised the need to look broadly at professional knowledge in a given environment, as professionals engage continuously and flexibly with each other and with professional knowledge-making itself in a particular area, in order to obtain expertise, networks and prestige, as opposed to more 'political' actors (as typically understood), who "come and go" based on policy interests or political limelight. Using Tsingou's distinction, professionals are engaged in "slow" rather than "fast" battles. As opposed to "fast" crises, where urgent political demands require quick relief, transnational professional competition can be understood as "slow", meaning that knowledge, policies and principles are "discussed, negotiated and produced in a longer time horizon" (2014:3).

As professionals compete for knowledge and prestige in transnational policy spaces, they shape the environments and the processes by which regulatory contexts - including for GWCs emerge. While existing research on professional competition and knowledge in the area of international taxation and global wealth chains has been limited, a cautiously emerging literature can be identified. Seabrooke \& Wigan (2013) have demonstrated how strategic leveraging of knowledge by civil society professionals in the NGO Tax Justice Network has transformed the discourse around corporate tax avoidance practices in captive and hierarchy wealth chains. Harrington (2012) has shown how the competitive behaviour of trust and estate planners underpin wealth management structures, where planners ensure secrecy for clients by managing domestic and international tax environments. More broadly, Picciotto $(1995,2015)$ has argued that lawyers and law firms, 
particularly Anglo-Saxon lawyers, were key in forming the international tax architecture, due to their ability to develop strong links within law and beyond and to dictate legal-technical tax policy debates.

In sum, the emerging 'transnational professionals' approach applied here offers an alternative perspective for analysing international tax reform and the regulatory context of global wealth chains, emphasising micro-level processes of professional competition and knowledge contestation. The analysis places professional interactions and professional knowledge at the centre, seeking to specifically uncover the locations and effects of power and authority in policy environments. It recognises the importance of professionals and knowledge in shaping transnational governance processes and global wealth chain governance, providing an apt lens for studying the practical policy environment of BEPS Action 13. The approach is operationalized through observation, interviews and sequence analysis, which illuminate professional characteristics and knowledge, interactions and policy arguments. I now turn to these methods.

\section{Data and Methods}

Using observation and interviews, I investigate the dynamics of the micro-level professional policy environment of BEPS Action 13. This allows for a detailed understanding of the policy process, the policy discussions and themes as seen by those involved, and the relationships among professionals. Through ethnographic direct and participant observation, the researcher seeks to witness practices and dynamics of specific groups of individuals in specific 'everyday' (here: professional) settings (Hammersley and Atkinson, 2007). The observational fieldwork for this study is drawn from participation at seven major international tax and TP events around Europe in 20132014, totalling around 100 effective hours of observation. In addition, 28 semi-structured, in-depth interviews with professionals engaged in the BEPS policy process were conducted in order to probe and strengthen working hypothesis and uncover alternative relevant dynamics. In this study, 
interviews and observation fieldwork were also applied to identify and classify important professionals in the policy environment, in the vein of prior micro-environment studies of professional dynamics (e.g. Lazega 2001). Specifically, this inquiry relied on network theory and relational analysis of the professional connectivity structures within which international tax policy emerges. The ability to access other nodes, form exchanges and spread ideas within the network are central to the policy environment. Particularly close attention is paid to professionals' access to and reach of weak ties, i.e. acquaintances or distant nodes. Information travels further between weak ties than strong ties (i.e. close friends) in networks, and thus weak ties are key for obtaining and diffusing (policy) ideas and knowledge (Granovetter, 1973).

In addition, sequence analysis was applied to study the careers of professionals involved in BEPS Action 13. Sequence analysis was originally used to analyse DNA successions, but has migrated via sociology to political science and international political economy (Abbott \& Tsay, 2000; Blanchard \& Fillieule, 2011; Seabrooke \& Nilsson, 2015). It allows the researcher to identify distinct trends and trajectories in careers, knowledge bases and the overall expertise environment. I apply 'optimal matching' (OM), an algorithm used to distinguish sequences (professional careers) by their "similarity" or "distance", i.e. by the minimal cost/effort of transforming one sequence into another (called 'matching'). From this, clusters of 'most similar' sequences are generated. Using LinkedIn, public data and manual inquiries, I obtained detailed career data for 98 professionals engaged in BEPS Action 13 spread across public/private sectors and various professions, representing a broad mix of professionals involved. To compare careers, possible work roles within the sample are categorised based on professional expertises present in BEPS Action 13: 
Figure 1. Main professional expertises in BEPS Action 13

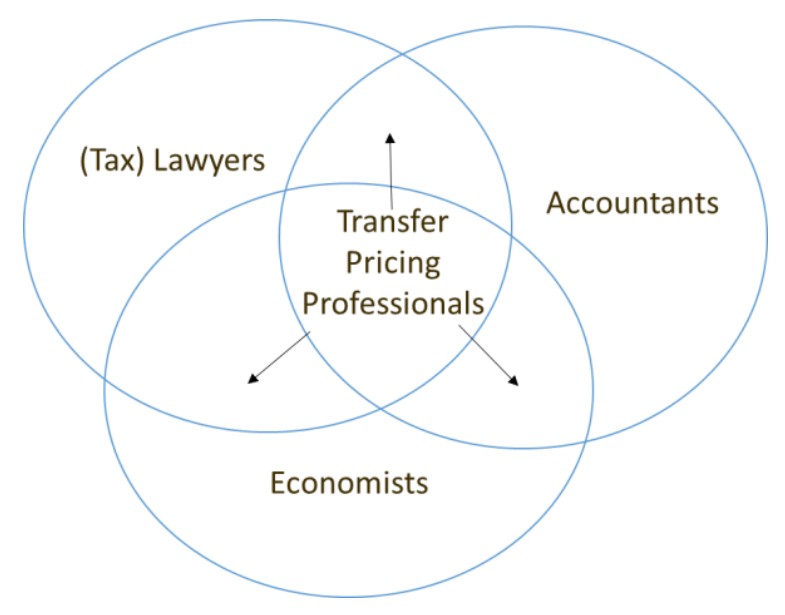

The categorisation combines different sectors (i.e. public sector, private sector, international organisation) and work roles from the crosscutting fields of academia and management. Table 1 presents the categories:

Table 1. Career states/work roles

\begin{tabular}{|c|c|c|c|}
\hline State code & Description & State code & Description \\
\hline ACA & Academia & MNPU & Senior manager in public sector \\
\hline ACIO & $\begin{array}{c}\text { Accountant/auditor in } \\
\text { international organisation (IO) }\end{array}$ & OTH & Other \\
\hline ACPR & $\begin{array}{c}\text { Accountant/auditor in private } \\
\text { sector }\end{array}$ & TLIO & Tax lawyers in IO \\
\hline ACS & $\begin{array}{c}\text { Accountant/auditor in public } \\
\text { sector }\end{array}$ & TLPR & Tax lawyer in private sector \\
\hline ECIO & Economist in IO & TLS & Tax lawyer in public sector \\
\hline ECPR & Economist in private sector & TPIO & $\begin{array}{c}\text { Transfer pricing professional in } \\
\text { IO }\end{array}$ \\
\hline ECS & Economist in public sector & TPPR & $\begin{array}{c}\text { Transfer pricing professional in } \\
\text { private sector }\end{array}$ \\
\hline MNIO & Senior manager in IO & TPS & $\begin{array}{c}\text { Transfer pricing professional in } \\
\text { public sector }\end{array}$ \\
\hline MNPR & Senior manager in private sector & & \\
\hline
\end{tabular}

Using the TraMineR for $\mathrm{R}$ software, this categorization is applied in 1-year instances to careers in the sample, providing an overview of career paths of BEPS Action 13 professionals. Furthermore, OM analysis reveals distinctive career trends by calculating distances and matching 
sequences. The distance costs determine what sequences are deemed similar and thus how sequences match (Lesnard 2010). There are two kinds of costs: the cost of substituting work roles and the cost of inserting/deleting ("indel") works role. The cost types are substitutive. If one cost type is high, the minimal transformation cost will rely more on the other. In short, substitutions regard whether a state occurs at the same time in different sequences, while indels regard whether a given state occurs at all (Aisenbrey \& Fasang 2010:426). Here, costs are defined deductively based on traditions in sociology combined with empirical observations. Substitution costs within a profession (e.g. from IO economist to private sector economist) and within a sector (e.g. from IO tax lawyer to IO senior manager) are defined to cost less than moves outside (e.g. from public sector accountant to academia), as the former work roles are more similar. A move to the same work role is no cost, while moves from the main professions into transfer pricing has a medium cost given the discipline overlap. The substitution cost matrix is provided in the appendix. Indel costs are set at two, slightly more than half the largest substitution cost (three). This focuses the analysis on the timing and order of work roles (rather than whether they occur at all) by limiting indel use (MacIndoe \& Abbott 2004:392). Data for the OM analysis consists of the past 20 years of the career sequences ${ }^{5}$. Using TraMineR, the OM algorithm is applied to generate four clusters of professionals. The results are discussed in section 4 .

\section{Global Tax Reform and Global Wealth Chains}

While BEPS is by no means the only noteworthy international tax reform project over the past few years, it is arguably the most significant in terms of affecting corporate wealth chains and corporate tax transparency. Over the past two decades, policy initiatives by the OECD, the G7/G8/G20, the EU

\footnotetext{
${ }^{5}$ A 20 -year time span (rather than 51, which is the longest career in the sample) allows for greater comparability across sequences. The majority of professionals in the sample have careers of 20 years or less; 20 years captures $80 \%$ of total career years.
} 
and the US have changed GWC regulatory environments through (automatic) exchange of tax information $^{6}$, blacklisting ${ }^{7}$, state aid $^{8}$, and corporate reporting 9 . But BEPS is particular because of its scope, promise, political support and forum. Envisioned regulatory changes are innovative and farreaching, tackling key international tax issues related to multilateral cooperation, international tax mismatches, transparency, and more. Political support for the initiative has also been marked. Just halfway through the project, two thirds of countries involved had implemented BEPS policy changes (EY, 2015a:2), and implementation has accelerated with the finalisation of the policy outputs ${ }^{10}$. Willingness to implement reflects wide acceptance of policy solutions developed leveraging the OECD forum's capacity for technical problem solving and diffusion of international tax standards (Vega, 2012; Christians, 2010; Sharman, 2012).

The impact of international tax reforms on the governance of global wealth chains can be substantial, and that certainly applies to BEPS and Action 13. International tax rules stipulating levels of corporate tax transparency fundamentally shape the political environment of global wealth chains by regulating the legality and feasibility (economic and normative) of corporate tax strategies and behaviour. In corporate wealth chains that apply cross-border tax planning strategies, transfer pricing documentation and country-by-country reporting rules form an essential part of the regulatory context. The scope, depth, timeliness and availability of corporate tax and transfer pricing reporting to tax authorities and other stakeholders plays a key role in the ability of these outsiders to decipher and intervene. And as all these elements are subject to change under BEPS Action 13, the policy process is a central space for change of the relationships and norms for businesses, tax advisers,

\footnotetext{
${ }^{6}$ E.g. Eccleston \& Woodward (2014), Palan \& Wigan (2014)

${ }^{7}$ E.g. Sharman (2009)

${ }^{8}$ E.g. EC (2014)

${ }^{9}$ E.g. PwC (2013)

${ }^{10}$ Action 13 uptake has been particularly speedy and widespread (see, e.g. EY, 2015b:16-17; Atlas Tax, 2016), and in January 2016, the European Commission proposed an Anti Tax Avoidance Package to implement other BEPS recommendations across the $\mathrm{EU}(\mathrm{EC}, 2016)$.
} 
authorities and other actors in the international tax space. Simply put, more information and greater disclosure imposes greater transparency on GWCs and international tax structures, increasing the regulatory pressure on corporate wealth chains. As Slemrod notes, "In modern tax theory, information is crucial, and the more information the better" (2006:4). Specifically, tax transparency contributes to a decrease in asymmetry of knowledge between business and tax advisers on the one hand and regulators on the other hand ${ }^{11}$.

The initial purpose set out by the G-20 and the OECD for Action 13 was to provide tax administrations with information necessary for TP risk assessment and ensure taxpayer compliance, considering business compliance costs (OECD, 2013; OECD, 2014a). In response, the OECD proposed a documentation package containing a master file with MNC group information relevant for all jurisdictions of operation, local files with information on the transactions relevant to a specific jurisdiction, and a country-by-country report (CBCR) obliging MNCs to disclose data as a group on income, economic activities, taxes, etc., for each jurisdiction in which they operate. This had been successfully promoted on to the G20/OECD agenda by civil society groups (author's interviews). The proposed package was more expansive than any previous initiative on corporate tax transparency (Herzfeld, 2014; compare with PwC, 2013). In terms of the envisioned access to filings, the entities covered and the scope of required data, the proposed Action 13 recommendations were groundbreaking.

Key points of debate in the policy discussions revolved around access, exemptions and data points in the documentation package. Access concerned the filing and sharing mechanism for the report (who can receive the information and how?). In terms of the impact on wealth chains, the easier access, the more transparency, and the more regulatory pressure. Civil society activists had proposed public documentation, while some emerging market representatives, incl. the BRICS, many of whom

\footnotetext{
${ }^{11}$ The increase in regulatory liability arrives both from greater access to information, which may reveal illegal behaviour, but also the increased scrutiny of corporate tax structures and tax planning.
} 
do not accord strictly to OECD transfer pricing standards, had generally been enthusiastic in promoting filing to each local subsidiary country's tax authorities. The majority of professionals engaged, however, including tax advisers and representatives from the US and Germany, favoured filing only to home country tax authorities, with international sharing through tax treaties under safeguard rules, in order to assure that company data would be handled with due care, confidentiality and compliance with OECD guidance. Discussion on exemptions concerned the pool of companies to file the CBCR, as well as the application of materiality standards (i.e. transactions below a certain monetary value to be excluded). Options varied, with experts proposing solutions ranging from no exemptions (very transparent) to high materiality standards and reporting thresholds (less transparent). Finally, the data points debate concerned the inclusion of specific data in the documentation, in particular the CBCR, such as cross-border payments, tangible assets, and number of employees. Simply, the more data points, the stronger basis for cross-national comparisons of profits and thus the greater regulatory and normative pressures on wealth chains. Here, activists and leading national transparency advocates, such as Norwegian representatives to the OECD, argued for expanded transparency, while again tax practitioners and US representatives favoured a slimmer CBCR to avoid unnecessary compliance costs.

These debates were contested by a broad but specialized group of actors engaged in highly technical policy discussions, many of which were Western tax practitioners equipped with complex tax and transfer pricing knowledge, with only a few non-technical experts, such as generalist activists. In this context, the overwhelming majority of professionals engaged in the BEPS Action 13 process favoured a relatively less transparent/free-flowing documentation package, with just the few activists favouring extensive, free-flowing documentation. The policy discussions were largely framed in highly detailed, specialist terms, dealing with micro-level technical solutions and specific expertisebased arguments, such as the feasibility of CBCR alignment with existing corporate accounting 
systems, rather than general political debate, such as the societal desirability of corporate tax transparency or its effect on corporate tax avoidance.

These technicised debates paved the way for the final BEPS Action 13 recommendations (OECD, 2014b; OECD, 2015a,b), which required MNC disclosure to tax authorities of unprecedented data on tax and transfer pricing strategies and outcomes. To stakeholders, whether this represents "going too far" or "not going far enough" remains open to interpretation ${ }^{12}$. However, agreed by more than 60 countries, the rules will form the basis for OECD/G20 countries' (and beyond) national TPD rules, reshaping fundamentally the transparency context of global wealth chains and corporate tax behaviour. The recommendations stipulate a CBCR template with seven data points (down from 15 in the discussion draft), applicable to all sectors, with filing limited to MNCs with more than $€ 750 \mathrm{~m}$ in annual revenue ${ }^{13}$. The master file will contain details on corporate structure and ownership, intangibles, tax rulings and more. The CBCR is to be filed with the MNCs' HQ home country and shared via tax treaties, thus limiting the availability of data to countries with few tax treaties, in particular developing countries, but fulfilling the wish of many technical experts in strengthening privacy protection of the data. In short, the new TPD rules will increase regulatory pressure on corporate tax affairs by providing regulators around the globe with substantially more information and decrease the information asymmetry between authorities and wealth chain insiders.

Having outlined the political context for and significance of BEPS Action 13 to international tax policy and the evolution of GWCs, the paper now turns to the analysis of the micro-level policy environment in which these rules developed as they did. Section 4 thus explores the professionals engaged in BEPS Action 13, their characteristics and networks, arguing that the policy process is critically conditioned by professional competition, based on professional expertise and networks.

\footnotetext{
${ }^{12}$ Compare Cobham (2015), arguing CBCR was "diluted in important ways", with Ernick (2015), who finds that the CBCR recommendations went far beyond the intensions.

${ }^{13}$ According to OECD estimates, this will represent $10-15 \%$ of MNCs but $90 \%+$ of global revenue.
} 


\section{Professional Competition in BEPS Action 13}

What kinds of professionals and knowledge are involved in the reworking international tax rules? The argument proposed here is that the BEPS Action 13 policy environment was critically shaped by professional competition for prestige and knowledge, based on expertise and networks. Professional expertise is significant to policy environments because policy claims are contingent upon it, both in the need to apply relevant expertise in policy claims and in the constraints placed on policy debates by the overall pool of professional expertise within the policy environment. The professional expertise(s) in BEPS Action 13 shaped the possible changes to the regulatory context of corporate wealth chains resulting from new TPD rules. Professionals draw upon the categories of professional expertise depicted in Figure 1 above (tax lawyers, accountants, economists and transfer pricing professionals) to lend traction to their policy claims. Professional networks complement expertise in shaping the policy environment by providing degrees of relational leverage for policy claims. Simply put, policy claims based on professional expertise are not necessarily influential if no one is willing to listen. "Good ideas are only powerful when those promoting them are well positioned within and across professional networks" (Burt 2010:256-7). Through personal socialisation and peer recognition, professional networks lead to common vocabularies and key relations, which can constrain or support the diffusion of certain ideas, thus shaping how policy knowledge is treated within the policy environment.

As another key component of professional competition, I also discuss below the nature and scope of 'revolving doors', i.e. strategic moves between work roles and sectors by professionals, enhancing their expertise, networks and prestige. Whereas revolving doors are typically understood as a "brain drain" from the public sector or a "regulatory capture" mechanism, here revolving doors are understood as an interactive process in a community of professionals that generates status and 
prestige. A diverse career provides professionals with more opportunities to access and apply relevant expertise and networks, potentially becoming prestigious 'epistemic arbiters' who "decide how to address transnational problems and who can address them" (Seabrooke 2014:50). 'Revolving door professionals', professionals with strong expertise, and well-networked professionals are expected to play a larger role in conditioning the policy environment. More broadly, the architecture of revolving doors and career paths for a given professional population is expected to shape the policy environment as certain combinations of knowledge and networks become prestigious. Below, the paper examines these features of professional competition in BEPS Action 13, to shed light on the policy environment and the policy process.

\section{Revolving doors and the policy environment}

To analyse the expertise and network features of the BEPS Action 13 professional environment, I first discuss the overall career trends of professionals involved and the prevalence and nature of revolving doors. Figures 4 and 5 below illustrate the career sequences of 98 professionals involved in the BEPS Action 13 policy process. Each line represents a career, in 1-year instances of work roles, sorted by career length (the longest careers are on top). Sequences are coloured according to the work role categorisation from section 2. Two different colour codings are used: one focused on professional roles (academic, economist, manager, tax lawyer, TP professional), another on sector (public, private, IO). In the figures, one professional career is highlighted for illustration. This person started their career in 1987, worked as a private sector transfer pricing professional for eight years, then as a private sector senior manager for six years, then as a public transfer pricing official for seven years, and most recently again as a private sector senior manager. 
Figure 4. Career sequences, colour-coded for professional roles (similar colours = similar professional roles)

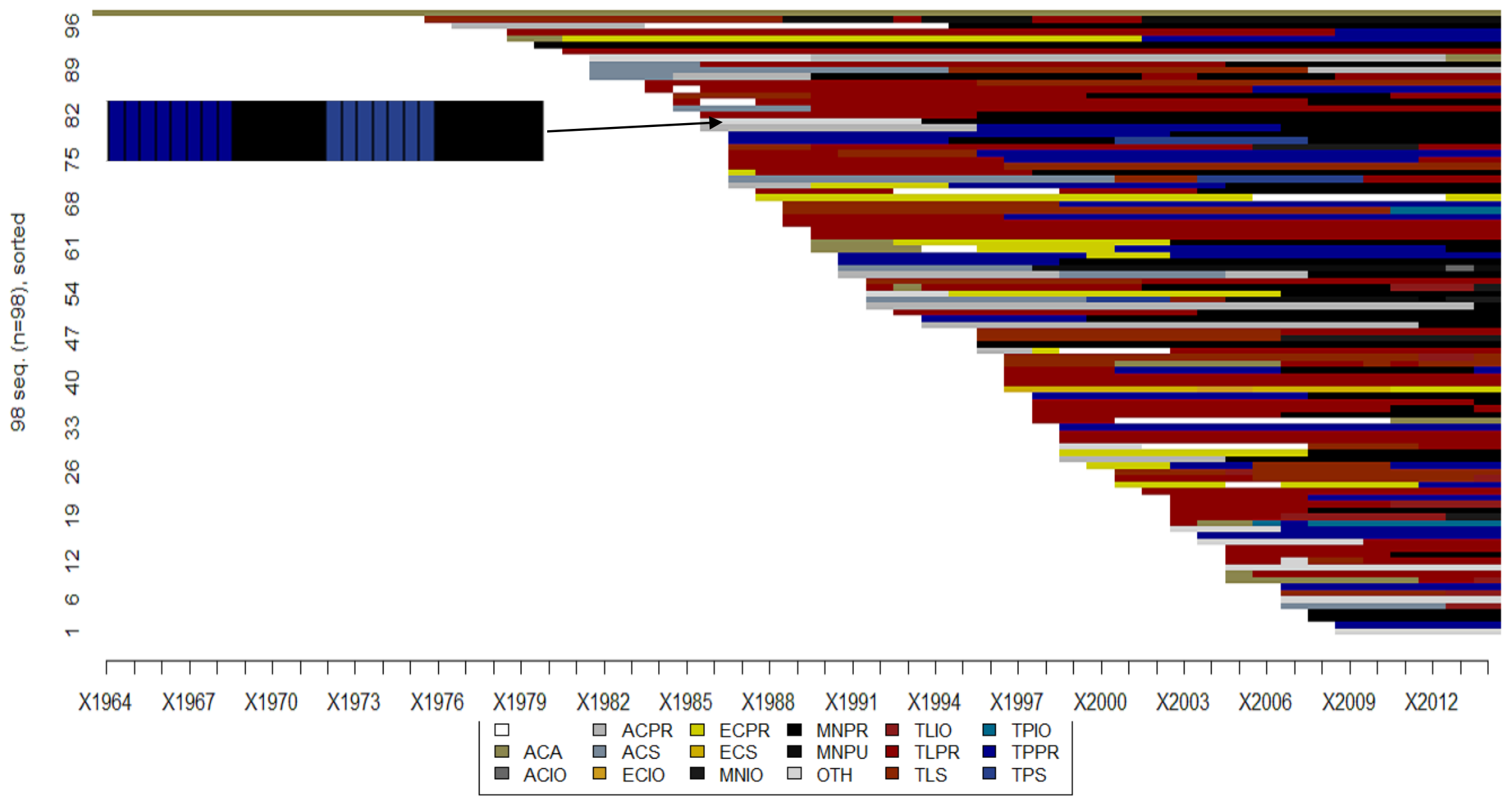


Figure 5. Career sequences, colour-coded for sector ( similar colours = similar sector $)$

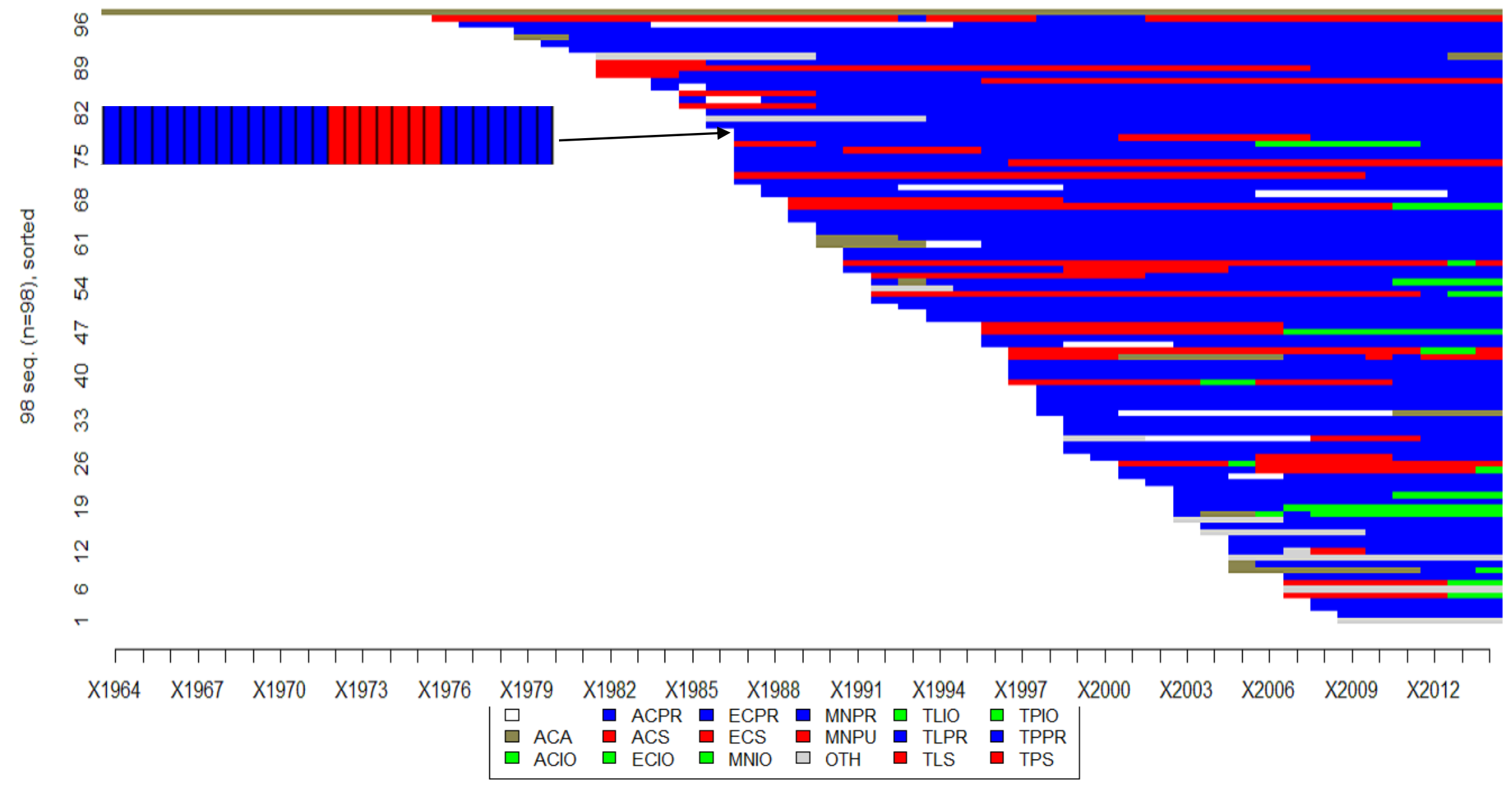


The figures reveal quite clearly the overall make-up of the BEPS Action 13 expertise environment. There is a strong prevalence of tax law (red in figure 4) and private sector (blue in figure 5) work roles, indicating the importance of these expertises in the BEPS Action 13 population. $42 \%$ of work role years are tax law, $73 \%$ are private sector. However, the figures also reflect the varied expertises in careers, with noteworthy amounts of TP professional expertise, management, accounting and economics.

To analyse the specific career types within the population, the OM analysis is deployed. Clusters generated from the OM algorithm are visualised in Figure 6 and 7. Once again, each line represents a professionals' career, in 1-year instances. Figure 6 is colour-coded for professional roles, figure 7 colour-coded for sector: 
Cluster 1
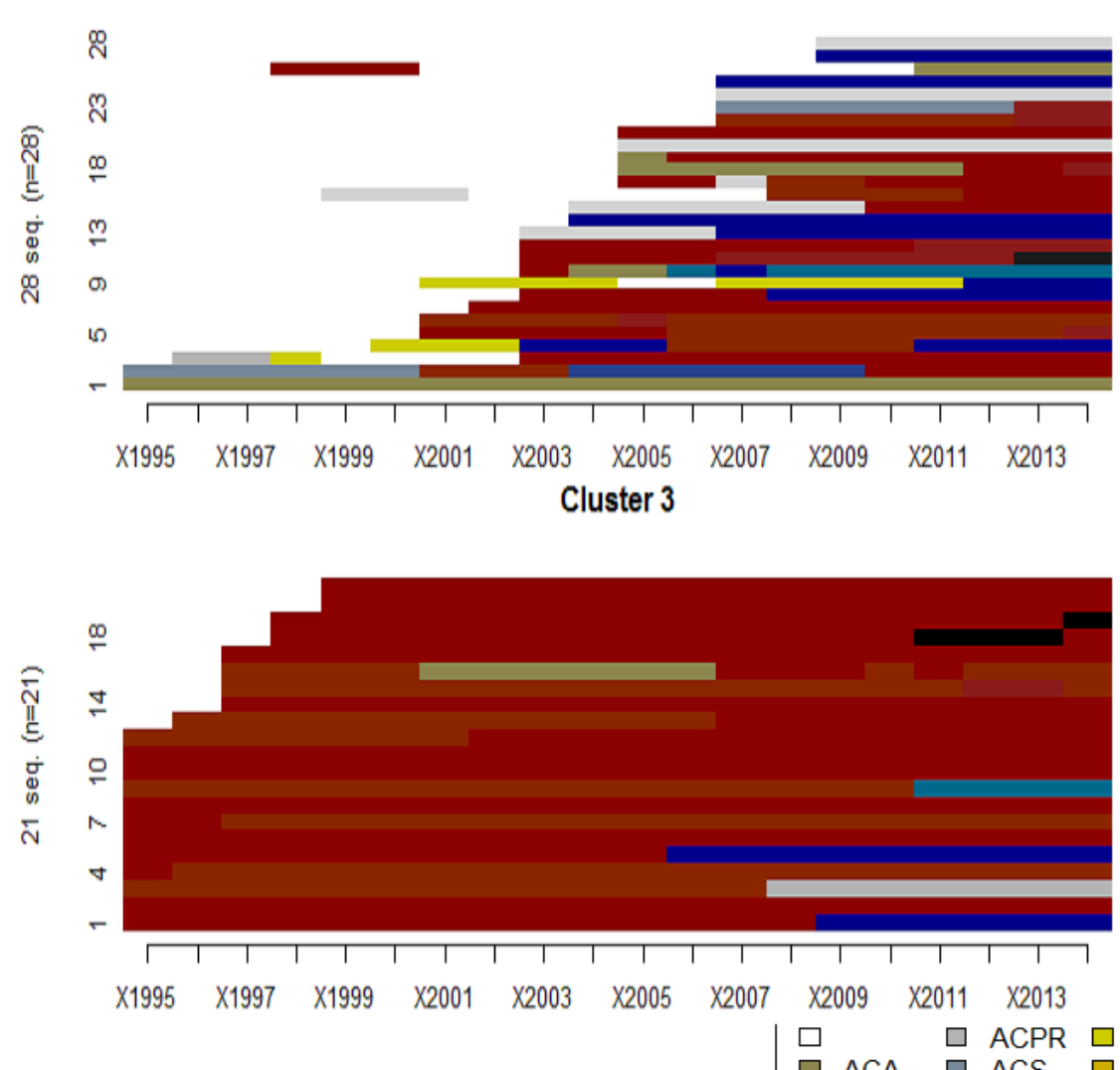

$\square$ ACA $\square$ ACS

$\square \mathrm{ACIO} \square \mathrm{ECIO}$
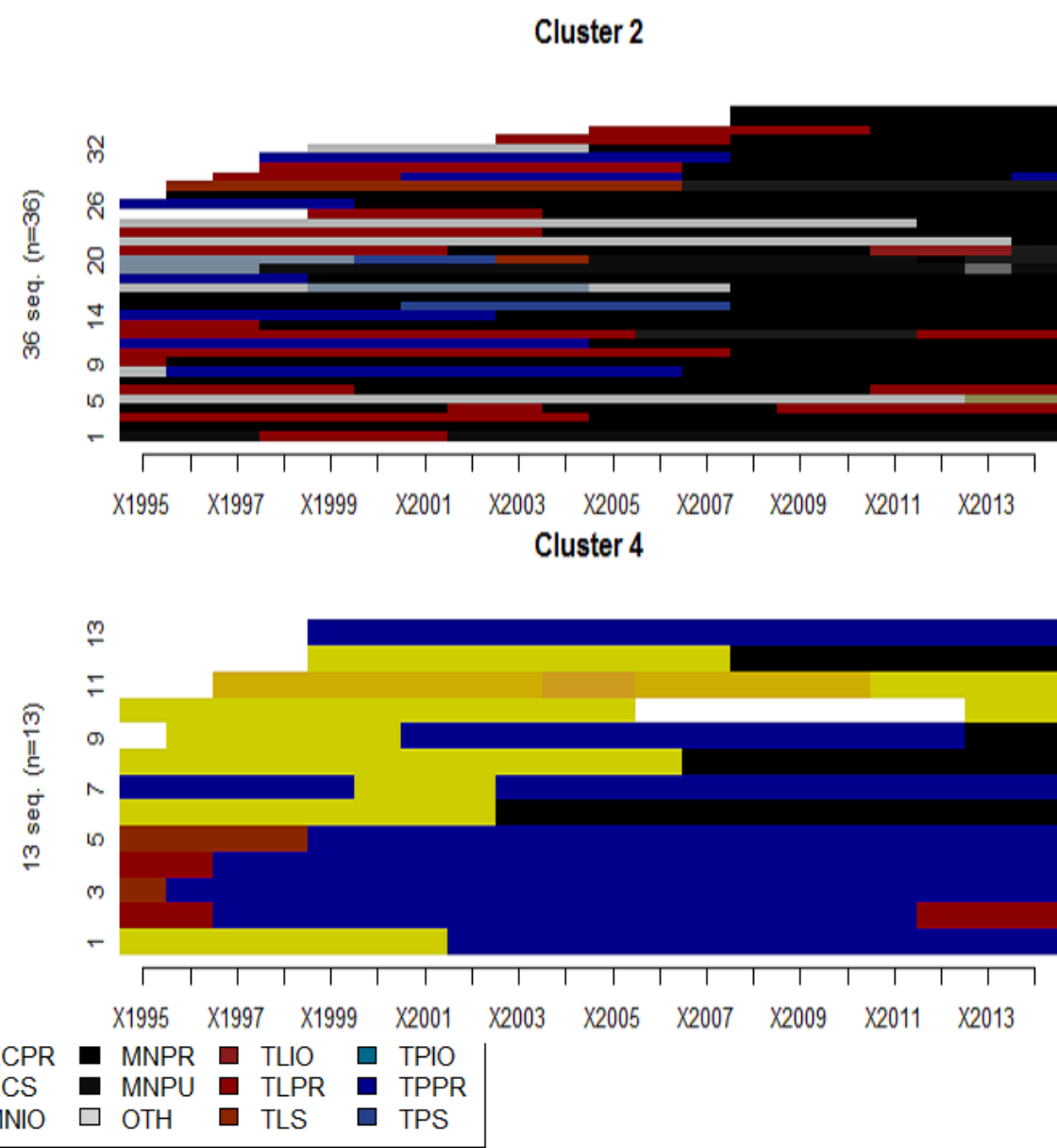
Cluster 1
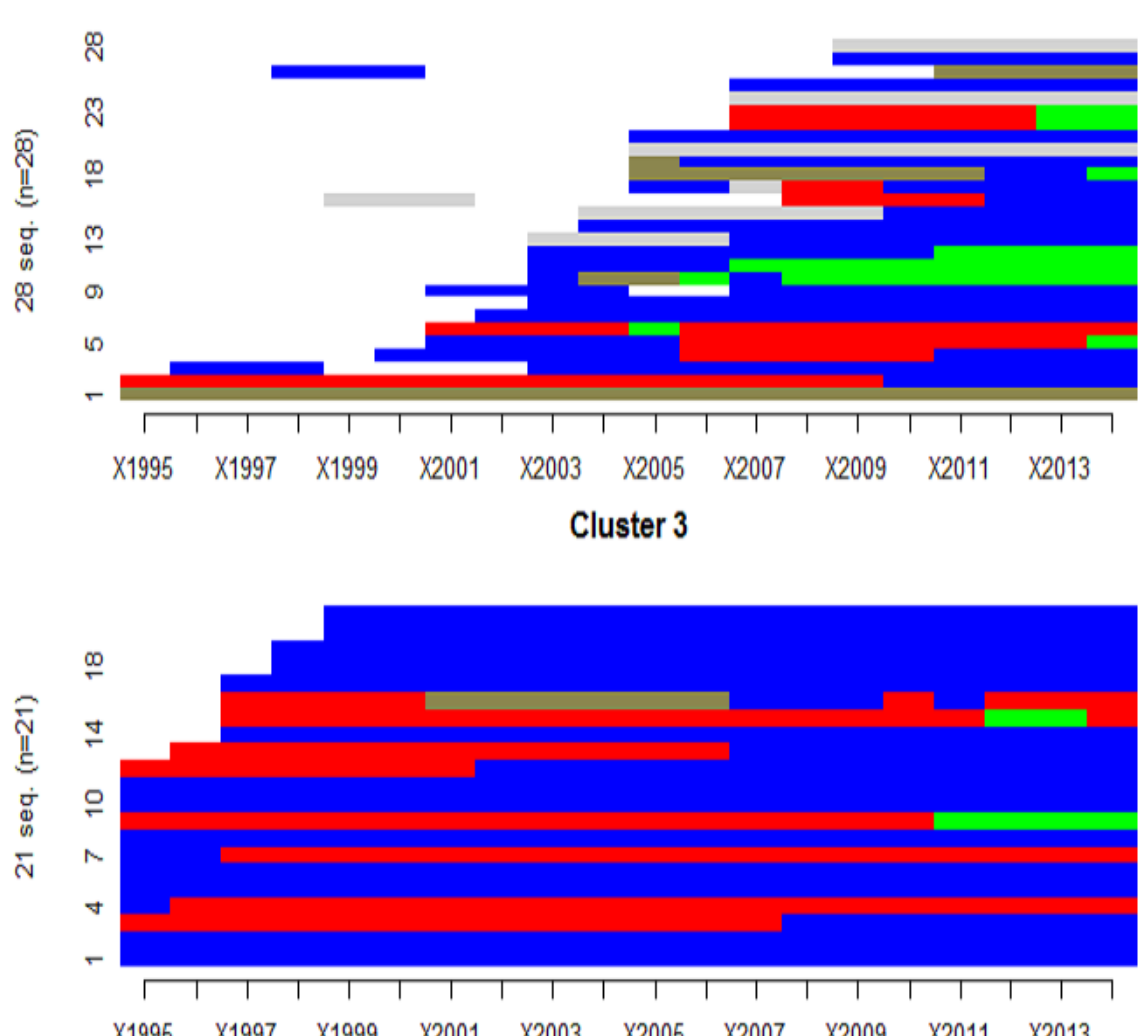

$\begin{array}{llllllllll}X 1995 & \times 1997 & \times 1999 & \times 2001 & \times 2003 & \times 2005 & \times 2007 & \text { X2009 } & \text { X2011 } & \text { X2013 }\end{array}$

$\square$ ACA $\square$ ACPR

$\square \mathrm{ACIO} \square \mathrm{ECIO}$
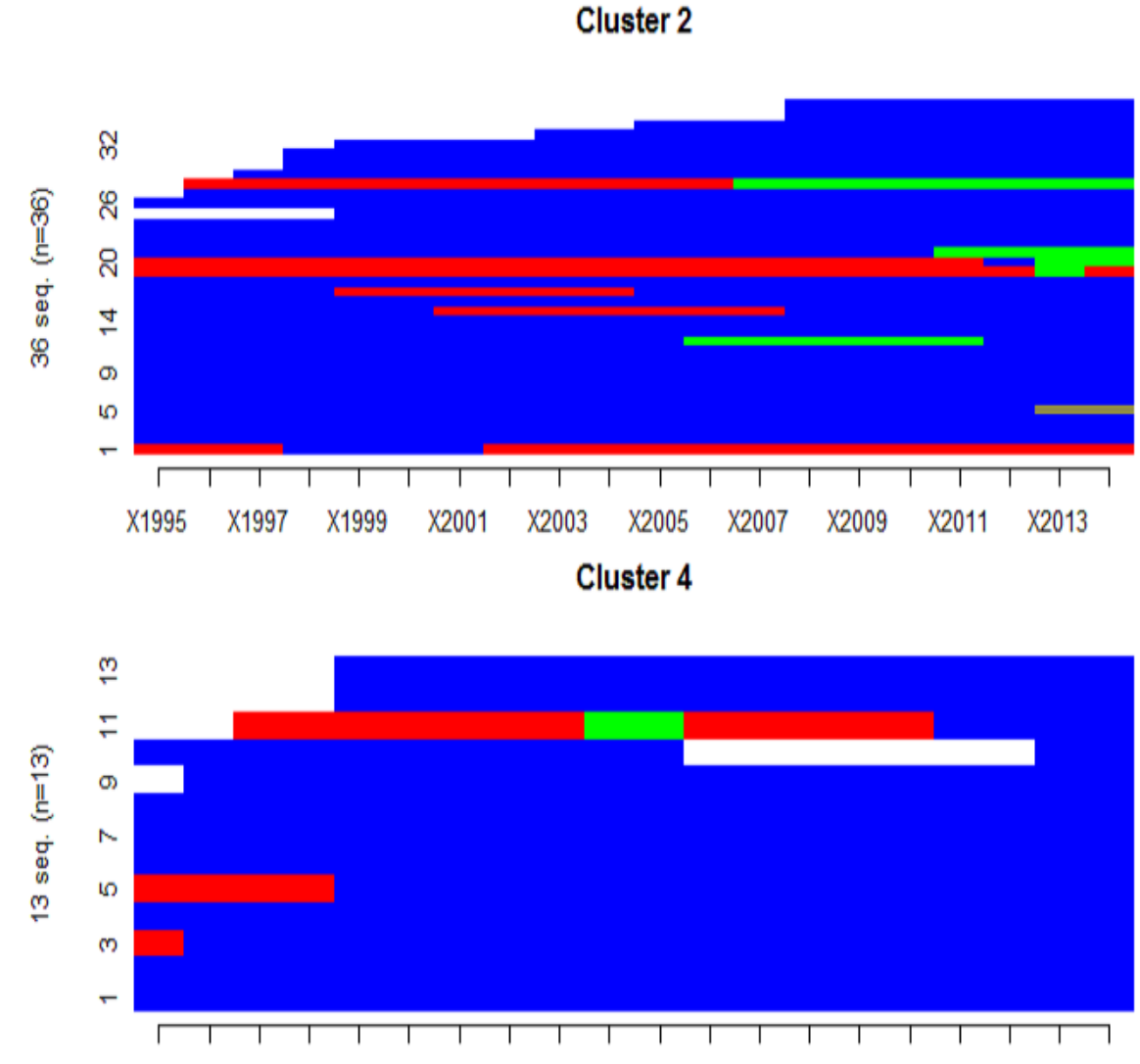

$\begin{array}{llllllllll}\text { X1995 } & \times 1997 & \times 1999 & \times 2001 & \times 2003 & \times 2005 & \times 2007 & \text { X2009 } & \text { X2011 } & \text { X2013 }\end{array}$

m MNPR $\square$ TLIO $\square$ TPIO

MNPU - TLPR — TPPR 
In numerical order, the clusters identify groups of professionals that can be labelled “youngsters", “experienced managers", "tax lawyers" and "TP/economists". To compare cluster expertise diversity, TraMineR's complexity measure is calculated, reflecting the variation or 'unusualness' of a career ${ }^{14}$; the higher the score, the more complex the career. Average complexity scores are shown for each cluster below:

Table 2. Clusters' career diversity

\begin{tabular}{|c|c|c|c|}
\hline No. & Cluster & $\begin{array}{c}\text { Number of } \\
\text { professionals }\end{array}$ & $\begin{array}{c}\text { Average complexity } \\
\text { score }\end{array}$ \\
\hline 1 & Youngsters & 28 & 0,099 \\
\hline 2 & Experienced managers & 36 & 0,142 \\
\hline 3 & Tax lawyers & 21 & 0,107 \\
\hline 4 & TP/economists & 13 & 0,139 \\
\hline
\end{tabular}

The experienced managers' cluster contains the most complex/diverse careers, indicating a relatively strong expertise base. Almost all the senior managers involved in BEPS Action 13 have prior practical expertise from legal, TP and/or accounting work roles, providing them the ability to access and leverage both different expertise bases for policy claims and different professional networks. The varied nature of managers' careers may reflect hierarchical work promotion structures within tax and transfer pricing disciplines. It also aligns with the revolving door argument posed here, that professional prestige and influence (expressed here as a management position) is contingent upon certain combinations of relevant, practical expertise.

The TP/economists cluster is the second most diverse, illustrating the cross-disciplinary nature of transfer pricing (cf. figure 1). Many cluster 3 professionals have both TP and economics experience, which reflects the increasing importance of economics for TP analysis. Participant

\footnotetext{
${ }^{14}$ Complexity is a composite, comparative (within the population) measure, dependent on the number of transitions in a sequence and the longitudinal entropy. Entropy can be interpreted as the total 'uncertainty' of predicting the states in a given sequence, given by the size of the alphabet and the proportion of occurrences of each particular state (career work role) in the sequences.
} 
observation in TP events supports this - detailed economic analysis is at the heart of discussions around TP practice.

The low career diversity of tax lawyers reflects the tendency for specialization within tax law, where professionals build up a significant body of expertise within one area due to topic complexity as well as market and career reward structures. Tax lawyers often stay within one expertise area, demonstrated in the monotonous career paths in the cluster (author's interviews).

Finally, while the least diverse "youngsters" cluster consists of many short, monotone careers, it also includes a sub-set of a few "young achievers" with short but diverse careers. They differ from the rest of the cluster in having covered a number of different work roles despite short professional lives. Interestingly, several of the "young achievers" now work in the OECD. This reflects OECD recruitment for BEPS positions, which specifically targets career diverse professionals with crosscutting diplomacy competencies (OECD Taleo, 2015; other job postings on file with author). It may also represent learning by young tax professionals that diverse careers lead to prestige, a trend that has been shown for young professionals at the IMF (Seabrooke \& Tsingou, 2015).

The analysis of careers and career diversity reveals the centrality of certain professional expertises in the BEPS Action 13 policy environment, in particular tax law. Furthermore, the centrality of combinations of professional expertise and the revolving door concept is particular visible among prestigious managers, economist-oriented TP professionals and young achievers. This architecture of career paths and diversity in the BEPS Action 13 population is central to professional competition, conditioning the policy environment as it advantages certain knowledge and certain networks over others. The relatively standing of professionals able to draw on, for instance, tax legal knowledge and career diversity, shaped the criteria for accepted arguments, and who was listened to in the policy process, as we shall see. 
One immediate consequence of the BEPS Action 13 expertise architecture was the technical nature of policy discussions. As noted above, the policy process was characterised by highly technical vocabularies of policy documents and discussions, in particular tax legal language. This provides a dense façade for the underlying, fundamental politics. As Ann Nolan of the Irish Ministry of Finance noted, "BEPS is technical in nature but political in flavour" (2014:8). Technicisation limits participation by actors who do not possess the required expertise - a feature disadvantaging, amongst others, civil society groups and non-Anglo-Saxon professionals ${ }^{15}$. One interviewee noted, in the policy debates, "it's about who opens their mouth", and those who do are more likely to have relevant expertise behind them (author's interviews). The primacy of and need for access to tax legal and private sector expertise were repeatedly highlighted in interviews. Almost the entire OECD BEPS secretariat were tax lawyers. A former OECD official also noted, "In OECD, there are some tax economists, and clearly different opinions between tax economists and tax lawyers, but the tax lawyers always win" (ibid.). There was also a widespread belief among interviewees that private sector practitioner perspectives were privileged in the Action 13 policy environment. One interviewee noted, "You need to 'spend time in the trenches' to meaningfully comment on the issues" (ibid.).

Another consequence was the need for tax legal and combinations of expertises in the policy environment, visible in professional careers and policy arguments. Of the 98 professionals in the population, two-thirds (65 professionals) had experience from at least two of the main professions and cross-cutting disciplines (noted in section 2), while the main career experience of 40 professionals was tax law. As such, arguments based on tax legal and combinations of expertises were abundant and privileged in the policy discussions, and many BEPS discussions observed relied predominantly on legal or combined expertises. For instance, tax legal and economic logics were applied in arguments for restricting the access to the TPD because of commercial sensitivity. Commenters

\footnotetext{
${ }^{15}$ The international tax regime is heavily based on Anglo-Saxon legal systems and values, thus favouring Anglo Saxon professionals in these discussions (see e.g. overview in Quack, 2007:648-9; Picciotto, 1995).
} 
argued that expansive documentation creates a competitive disadvantage for businesses and legal uncertainty and privacy concerns, contrary to the basic doctrines of the rule of law. The Business and Industry Advisory Committee to the OECD (BIAC) comment letter cited a long list of information in the proposed documentation that "largely relates to highly confidential or commercially sensitive information, and, if inadvertently shared beyond the intended recipient, could present a significant risk to the group in question" (BIAC, 2014:19). Ivins, Phillips \& Baker argued, "The obvious concern here is that this information may then be used for improper purposes (e.g., to exploit local affiliates)" (IPB, 2014:5).

Accounting expertise was also mobilised for arguments, but importantly such arguments were less well-received. Accounting-based arguments were particularly prevalent when discussing the (in)compatibility of with existing accounting systems with the proposed documentation requirements; simply, the required data "could not be gathered". Thus, EY argued:

"The information the OECD is seeking with this template generally is not information that is collected by MNC groups in such form for any other purpose. There is no single optimal data source that could be required to be used to populate the template”. (EY, 2014:5)

This type of argumentation found relatively little traction. An accountant, who engaged extensively with BEPS Action 13, noted, "Action 13 is a "tax lawyers' output", tax lawyers talking to each other in tax technical language. But they lack practical accounting knowledge, which is what I attempted to provide, but they didn't really listen to my concerns" (ibid.). Among professionals engaged in the process, little attention was afforded to accounting perspectives, reflecting the relatively insignificant accounting expertise throughout the population (grey in figure 4), compared to other types of expertise. 
The career diversity of professionals and the architecture of revolving doors thus condition the transnational policy environment by favouring certain (combinations of) expertise, certain policy arguments over others, and certain types of professionals over others. In the next section, I distinguish two types of professionals particularly central in the Action 13 policy environment: "octopuses" and "arrows" - respectively, career diverse professionals and narrow expert specialists that are well connected throughout key networks within the professional environment, such as professional associations and tax committees.

\section{Octopuses, arrows and lobby centres}

Whereas "octopuses" are important to the policy environment primarily due to their career diversity and prominent combinations of expertise, "arrows" are important because they have come to be perceived as 'knowing well' within a specific field by leveraging network positioning for professional prestige (Seabrooke, 2014). Octopuses in BEPS Action 13 are, in particular, professionals with combinations of tax law and management expertise, many with secondary expertise in $\mathrm{TP}$ or accounting, who conditioned the policy environment by applying relevant knowledge in framing the policy debates. Arrows, meanwhile, are central to the policy environment due to positioning in key tax networks, through which ideas around Action 13 emerged and spread within and across groupings. To illustrate: Octopuses successfully promoted arguments that expansive CBCR was undesirable because of legal uncertainty and economic inefficiency, drawing on central tax expertise; arrows facilitated the diffusion through key tax networks of policy consensus around commercial sensitivity concerns for $\mathrm{CBCR}^{16}$. In doing so, arrows in BEPS Action 13 leveraged their positioning and

\footnotetext{
${ }^{16}$ The 'octopus' and 'arrow' characteristics of BEPS Action 13 professionals and their effects on the policy environment and process do, of course, overlap, and there were a number of professionals with characteristics of both types.
} 
connections in key professional and business associations and national tax authorities, as well as international organisations, think tanks, universities and other expert networks.

The arrows of BEPS Action 13 share certain particular characteristics. One important characteristic is connectedness through professional and business associations. Associations are as social network sites and sites of professional expertise for rule making (Greenwood et al., 2002; Quack, 2007). They provide loose and firm network access through which policy knowledge can move swiftly. Several professionals noted in interviews that access to weak ties (acquaintances) was a main reason for their participation in associations relevant to BEPS Action 13 (author's interviews).

Professionals from more than 50 professional associations formally participated in Action 13, but one stands out in terms of importance to the BEPS Action 13 professional network: BIAC - the "voice of business at the OECD" - an institutionalised lobby group firmly embedded in OECD tax work. BIAC is the umbrella for national business associations and other professional bodies, with a small secretariat and a number of specialised committees, such as the tax committee. Key BIAC professionals involved in the tax committee, in particular its esteemed Chair and Vice-Chairs, are highly respected and have strong links with and favourable access to other key professionals. One BIAC member acknowledged this, citing "under the table" leaks of OECD policy documents as one example. Another interviewee, a former OECD, noted, "BIAC is given more access. Pascal [SaintAmans, Director of OECD Centre for Tax Policy and Administration] is more likely to meet with BIAC bilaterally than others". BIAC tax experts act as gatekeepers for other professionals and their ideas in OECD policy processes, and as leaders in "opinion socialising" and building and spreading policy consensus. BIAC-centred professional networks were key to the diffusion of the consensus that confidentiality around TPD was vital through global business associations' tax committees, national associations, businesses and onwards (ibid.). Many professionals engaged in BEPS Action 13 participated in several key associations, a practice known as "double-hatting". For instance, there 
is significant overlap between professional tax networks of BIAC, the International Chamber of Commerce (ICC) and BusinessEurope. This creates a highly connected network and knowledge environment, through which policy ideas are supported or constrained. A tax lawyer, and BIAC and BusinessEurope tax committee member, commented on the associations' BEPS engagement: "The group of people involved in the process is relatively small, so we see each other regularly. The consensus on business side is massive for almost all Action points" (ibid.).

Besides centrality through tax associations and committees, most Acton 13 arrows were tax lawyers or TP professionals, and most were Anglo-Saxon or Dutch professionals. Many of the formalised networks through which the arrows operate also align with this characterisation. The BIAC and ICC tax committees are dominated by well connected US and UK experts. A former OECD employee, who had worked on BEPS, said, "With BIAC, which is very strongly ruled by US and UK representatives, they have a strong relationship and involvement; they and OECD staff all know each other very well. They are extremely chummy." (ibid.). One reason for the standing of Anglo-Saxon professionals is language barriers, both English language and tax legal language. English is the working language in many associations and networks, so English skills matter for engagement, including in OECD Working Parties (Johnston, 2013). And the international tax regime is strongly grounded in Anglo-Saxon legal systems, thus favouring Anglo-Saxon professionals (Quack, 2007).

Anglo-Saxon professionals' greater connectedness are built on top of strong national networks. The UK and US have liberal market economies that promote market mechanisms and actors (Hall \& Soskice, 2001). For instance, the UK tax authority (HMRC) has an emphasised structure of stakeholder councils, engages heavily with private professionals, and there are strong personal connections between top UK tax professionals across the public and private sectors (author's interviews). Similarly to the UK and US, there are strong Dutch national networks of professionals working on international tax, with revolving doors prevalent. The Dutch have a historically central 
role in international tax matters and have been a key site for tax expertise for many decades (ibid.). It is useful to highlight one arrow in illustration. One UK arrow is a tax lawyer working for a major US MNC; he holds prominent positions in the BIAC and CBI tax committees; he is an engaged stakeholder with the HMRC, and manages an extensive personal network of US and UK international tax professionals. An interviewee, describing the close personal network of the arrow in question (of which the interviewee is part), noted that those connections were "important for being heard at the OECD" (ibid.). Another former OECD employee said of the same arrow: "He and Pascal (SaintAmans) have a very close relationship, they talk on the phone all the time, they meet all the time at these different international conferences; they can easily pick up the phone and smooth over the problems". Clearly, this arrow held an important position in the Action 13 policy environment.

'Arrow' professionals, alongside octopuses, are important pieces in the professional knowledge architecture and policy environment of BEPS Action 13. The centrality of well-connected professionals has been highlighted in previous work on 'corporate elite networks' (e.g. Apeldoorn \& de Graaff, 2012) and 'flexians' (Wedel, 2009). But while these works stress the importance of being connected through diverse networks - e.g. having roles in media, consulting, executive management and politics - the arrows of BEPS Action 13 shows that belonging to many different networks might not be necessary for policy importance. Rather, it may be attained if a professional is connected through the right networks within the specific professional space (here: international tax).

In sum, being connected right and having access to the right combinations of expertise contribute significantly the professional prestige, shaping professional competition in the policy environment and, in the end, affecting fundamentally policy outcomes. More broadly, it informs understanding of professional engagement in transnational policy processes. Octopuses and arrows are central characters in the policy environment; if an octopus or an arrow is leveraging their prestige to advance a particular case, that case is simply more likely to succeed. Many professionals and 
organisations are aware of this, and structure their policy engagement accordingly. Some interest groups (e.g. NGOs) deliberately abstain from engagement in transnational policy processes (e.g. on tax) because they lack access to technical expertise. Other interest groups are specifically geared to leverage expertise and networks in the professional environment. For instance, the face of one Big 4 audit firm's Action 13 engagement, a Dutch professional, is internally referred to as "the OECD partner", due to his particularly suitable expertise and networks to OECD policy processes. Such engagement strategies are rarely emphasised in the existing literature on transnational policy processes, but the case of BEPS Action 13 provides a particularly good illustration of why they matter: lobby centres.

The leveraging of octopuses and arrows' characteristics in the Action 13 process is clearly visible in what I term "lobby centres". Lobby centres are BEPS- or tax-specific lobby groups, consisting of several organisations, fronted by appointed octopus/arrow. Lobby groups leverage influential professionals' expertise and networks or connect several professionals in order to create strongly expertised and networked alliances. Most BEPS Action 13 lobby centres are business lobbies, where the appointed leader is not employed with any of the participating businesses. The use of an unaffiliated professional as a 'figurehead' comes, for some lobby centres, from a reluctance to publicise an organisation's involvement and opinions. More importantly, the use of octopuses and arrows signals a desire to leverage the prestige of these professionals. Many octopus/arrow professionals leading lobby centres also have experience working in or with the OECD. This may enhance the positioning of lobby centres, as experience within the policy environment facilitates alignment to the knowledge architecture of BEPS Action 13.

The only civil society lobby centre involved in BEPS Action 13, the BEPS Monitoring Group, also sheds light on an interesting professional engagement strategy uncommon to civil society groups in the international tax space. Compared to business groups, NGOs generally have fewer resources 
to engage in transnational policy processes, including less professional expertise and network positioning in tax and transfer pricing spaces. Traditionally, NGO participation in technical tax and TP debates has been limited. Instead, they have prioritised wider campaigning for public salience. However, if NGOs are to impact tax/TP policy environments, they may need to acquire/access prestige or create alliances to the same effect. This is what the BEPS Monitoring Group has done by combining relevant expertises from different professionals (technical experts, academics, campaigners) across several professional fields, separate from their organisational belonging (members participate in the group in their personal capacity), and by leveraging network access and prestige of key professionals. The BEPS Monitoring Group structure is close to that of the Tax Justice Network, as discussed by Seabrooke \& Wigan (2013). Not coincidentally, there is significant overlap in the two groups' membership. And indeed, a number of influential civil society professionals associated with the BEPS Monitoring Group were engaged in Action 13.

The notion of lobby centres sheds light on an aspect of transnational policy processes that existing literature rarely touches upon, namely the specific role of professional skills and networks in mobilisation strategies and decisions. The literature on "transnational advocacy networks" has recognised that successful policy engagement is not merely about participation ("being there"), and that global actors do mobilise to complex policy processes by creating "transnational advocacy networks" (Carpenter, 2007; Tomaskovic-Devey et al., 2011). And the interest group literature has shown that private sector coalitions, such as those created through lobby centres, are key to global policy environments (Pagliari \& Young, 2014). But work on lobbying strategies based on professional expertise and networks is limited. Keck \& Sikkink (1998) show that information tactics are key to NGO pressure for influence, and Seabrooke \& Wigan (2013) explain the Tax Justice Network's influence through strategic application of expertises by various professionals. However, the analysis offered here provides an account of lobbying strategies that applies to a broader range of organisations 
and professionals, showing how different groups from different sectors engage, mobilise and leverage expertise and networks around a key global political reform.

\section{Conclusions}

In the context of the global financial crisis, with states under fiscal pressures and increasing demands for reform of international corporate taxation, the Base Erosion and Profit Shifting (BEPS) project emerged as the key global tax reform, poised to effect wholesale change to the global tax landscape and to global wealth chains. BEPS Action 13 on transfer pricing documentation and country-by-country reporting is particularly significant, producing new rules that impose unprecedented transparency on MNCs' tax and transfer pricing practices. The regulatory, political and normative outcome will reconfigure transfer pricing strategies and corporate tax behaviour. For corporate wealth chains that utilise transfer pricing and tax structures to shift profits, the direct result is decreased information asymmetry between regulators and MNCs and their advisers, and thus increased regulatory pressure.

The paper has offered a micro-level analysis of the professional competition in BEPS Action 13, arguing that professional dynamics, based around expertise and networks, plays a central role in shaping the policy environment and process. The approach builds on but complements existing IPE work that highlights state power, regulatory capture and IO pathologies in conceptualising the agency driving global policy reforms. In BEPS Action 13, highly technical policy discussions required specialised expertise to meaningfully participate, and were contested by a range of expert professionals engaged in interactive exchanges that shaped the policy process by conditioning what could be discussed, the criteria for accepted arguments, and who was listened to. The case study has drawn on fieldwork in and analysis of the international tax and transfer pricing community throughout 2014-16, including interviews, observation and sequence analysis of professional CVs. 
Relevant professional expertise underpins policy claims and networks provide relational leverage in the policy environment. Key professionals in BEPS Action 13 were able to access skills and connections, including by having gone through revolving doors. The paper distinguishes two types of important professionals: octopuses (career diverse professionals with varied expertise) and arrows (specialists well connected through key tax networks, such as professional associations and tax committees). Career sequence analysis and 'optimal matching' has revealed the Action 13 knowledge architecture and specific career types in the professional population, which are grouped into tax lawyers, experienced managers, transfer pricing professionals/economists and youngsters. Octopuses in BEPS Action 13 were often professionals with combinations of tax law and management expertise, many with secondary expertise in transfer pricing or accounting, who made their mark on the policy process by applying combinations of prominent expertises and framing policy debates in acceptable and accepted terms. Arrows were largely Anglo-Saxon and Dutch professionals, reflecting the strong networks and revolving doors within these professionals' tax and transfer pricing environments. Arrows shaped the policy environment through network positioning, utilising their relational advantage for disseminating consensus and ideas, in particular through top tax committees and associations such as BIAC. Finally, "lobby centre" strategies in BEPS Action 13 revolved around the leveraging octopus and arrow professionals, using their privileged standing and resources to 'figurehead' causes and policy claims on behalf of other organisations and professionals. The widespread use of lobby centre strategies, including within civil society (the BEPS Monitoring Group) points to an important yet underutilized and understudied mobilisation strategy by NGOs on technical transnational policy processes.

Implications of these findings can be identified at the theoretical and empirical levels. Firstly, the paper serves as an important reminder that professional competition is critical to understanding transnational policy processes like BEPS Action 13. As cross-border rule making is becoming more 
transnationalised, with technically complex regulation formed in spaces separated from national arenas, the affording professionals greater opportunity and incentive to engage. In such processes, the dynamics of professional competition are particularly important and fruitful avenue for future research on transnational regulatory contexts and political processes. The paper contributes to an interesting, emerging literature by extending the work professional competition in global policy reform processes to the sphere of international taxation. However, given the limited empirical scope of the paper, more research is welcomed and needed on related issue areas, such as banking and financial regulatory reform, and in related policy forums, such as the European Union and the United Nations.

At the more practical level, the paper has implications matters for actors' engagement with transnational policy processes. For all actors involved, there is a need to recognise the importance of professional competition, professional expertise and professional networks in shaping policy processes and policy outcomes. For instance, if international organisations want to structure policy processes to accommodate a wide range of interests, they must account for professional competition and the professional/technical barriers to mobilisation. Similarly, if (groups of) professionals want to successfully engage in such policy environments, access to networks and expertise are imperative. Alternatively, interest groups may seek to leverage the prestige of others. 


\section{References}

Abbott, A. (1988) 'The System of Professions', Chicago: University of Chicago Press.

Abbott, A. (2005) 'Linked Ecologies: States and Universities as Environments for Professions', Sociological Theory, 23(3).

Abbott, A., and Tsay, A. (2000) 'Sequence Analysis and Optimal Matching Methods in Sociology: Review and Prospect', Sociological Methods \& Research, 29(3).

Abbott, K. W. and Snidal, D. (2009) 'The Governance Triangle: Regulatory Standards Institutions and the Shadow of the State' in: Mattli, W. and Woods, N. (eds) The Politics of Global Regulation, Princeton: Princeton University Press, pp. 44-88.

ActionAid UK (2014) 'The BEPS process: failing to deliver for developing countries', $<$ http://actionaid.org/sites/files/actionaid/the_beps_process_failing to_deliver_for_developing_countries_0.pdf>; (accessed 24 July 2015)

Adolph, C. (2013) 'Bankers, Bureaucrats, and Central Bank Politics: The Myth of Neutrality', Cambridge: Cambridge University Press.

Apeldoorn, B. v., and de Graaff, N. (2012) 'Corporate Elite Networks and US Post-Cold war Grand Strategies From Clinton to Obama', European Journal of International Relations, <http://ejt.sagepub.com/content/early/2012/06/22/1354066111433895>; (accessed 24 July 2015)

Atlas Tax (2016) 'Country-by-country reporting implementation map', <http://www.atlastax.nl/services/transfer-pricing/country-by-country-reporting-implementation-map >; (accessed 21 February 2016)

Baker, A. (2010) 'Restraining regulatory capture? Anglo-America, crisis politics and trajectories of change in global financial governance', International Affairs, 86(3):647-663.

Barnett, M., and Finnemore, M. (1999) 'The Politics, Power, and Pathologies of International Organizations', International Organization, 53(4):699-732.

Barnett, M., and Finnemore, M. (2004) Rules for the World: International organizations in world politics. London: Cornell University Press.

BIAC (2014) 'Comment letter on discussion draft on transfer pricing documentation and $\mathrm{CbC}$ Reporting', <http://www.oecd.org/tax/transfer-pricing/comments-discussion-draft-transfer-pricingdocumentation.htm>; (accessed 24 July 2015)

Blanchard, P., and Fillieule, O (2011) 'Sequence Analysis for Political Science', Paper prepared for the 2011 Annual Meeting of the American Political Science Association, September 1-4, 2011, <http://ecpr.eu/filestore/paperproposal/dc3c33cc-a493-474b-ae3c-b02b8a2460ed.pdf>; (accessed 24 July 2015)

Borkowski, S. (2006) 'Turnover in Transfer Pricing Management: Revolving Door or Opportunity for Expertise', International Tax Journal, Spring 2014. 
Botzem, S. (2008) 'Transnational Expert-Driven Standardisation. Accountancy Governance from a Professional Point of View' in Graz, J-C. and Nölke, A., (eds.) Transnational Private Governance and its Limits, London/New York, NY: Routledge, pp. 44-57.

Botzem, S. (2012) The Politics of Accounting Regulation: Organizing Transnational Standard Setting in Financial Reporting, Cheltenham/Northampton, MA: Edward Elgar.

Bourdieu, P. (1986) 'La force du droit: elements pour une socioligie du champ juridique', Actes de la recherche en sciences sociales, 64:3-19.

Bourdieu, P. (1987) 'The force of law', Hastings Law Journal, 38:814.

Bourdieu, P. (1993) The Field of Cultural Production, New York: Columbia University Press.

Burt, R. (2010) Neighbor Networks, Oxford: Oxford University Press.

Carpenter, R. C. (2007) 'Setting the Advocacy Agenda: Theorizing Issue Emergence and Nonemergence in Transnational Advocacy Networks', International Studies Quarterly, 51:99-120.

Christians, A. (2010) 'Networks, Norms, and National Tax Policy', Washington University Global Studies Law Review, 9(1).

Christians, A. (2012) 'Tax Activists and the Global Movement for Development through Transparency' in Stewart, M. and Brauner, Y., (eds.) University of Wisconsin Law School Legal Studies Research Paper Series, Tax and Development, No. 1193.

Cobham, A. (2015) [blog post] 'OECD country-by-country reporting: Strangled at birth', 8 June 2015, <http://uncounted.org/2015/06/08/oecd-country-by-country-reporting-strangled-atbirth/>; (accessed 24 July 2015)

Dezalay, Y., and Garth, B. G. (1995) 'Merchants of Law as Moral Entrepreneurs: Constructing International Justice from the Competition for Transnational Business Disputes', Law \& Society Review, 29(1):27-64.

Dezalay, Y., and Sugarman, D. (1995) Professional Competition and Professional Power: Lawyers, Accountants and the Social Construction of Markets, London: Routledge.

Djelic, M-L., and Quack, D. (eds). Transnational communities: Shaping global economic governance. Cambridge University Press, 2010.

EC [European Commission] (2014) [press release] State aid: Commission investigates transfer pricing arrangements on corporate taxation of Apple (Ireland) Starbucks (Netherlands) and Fiat Finance and Trade (Luxembourg), <http://europa.eu/rapid/press-release_IP-14663_en.htm>; (accessed 24 July 2015)

EC [European Commission] (2016) [press release] Fair Taxation: Commission presents new measures against corporate tax avoidance, < http://europa.eu/rapid/press-release_IP-16159 en.htm>; (accessed 21 February 2016)

Eccleston, R. and Woodward, R. (2014) 'Pathologies in International Policy Transfer: The Case of the OECD Tax Transparency Initiative', Journal of Comparative Policy Analysis: Research and Practice, 16(3):216-229. 
Ernick, D. (2015) 'Will Public Disclosure of Country-by-Country Reporting Data Become Mandatory?, <http://www.bna.com/public-disclosure-countrybycountry-n17179927428/>; (accessed 24 July 2015)

EY (2014) 'Comment letter on discussion draft on transfer pricing documentation and $\mathrm{CbC}$ Reporting', <http://www.oecd.org/tax/transfer-pricing/comments-discussion-draft-transfer-pricingdocumentation.htm>; (accessed 24 July 2015)

EY (2015) 'The outlook for global tax policy in 2015', <http://www.ey.com/Publication/vwLUAssets/ey-global-tax-policy-outlook-for-2015/\$FILE/ey-globaltax-policy-outlook-for-2015.pdf> (accessed 24 July 2015)

EY (2015) 'Country implementation of BEPS Actions 8-10 and 13', $<$ http://www.ey.com/Publication/vwLUAssets/ey-country-implementation-of-beps-actions-8-10and-13-august-2015/\$FILE/ey-country-implementation-of-beps-actions-8-10-and-13.pdf> (accessed 21 February 2016)

Faulconbridge, J. and Muzio, D. (2011) 'Professions in a globalizing world: Towards a transnational sociology of the professions', International Sociology, 18.

Fourcade, M. (2006) 'The Construction of a Global Profession: The Transnationalization of Economics', American Journal of Sociology 112:145-194.

Gentschel, P., and Seelkopf, L. (2015) 'Winners and Losers of Tax Competition' in Dietsch, P., and Rixen, T. (eds.) Global Tax Governance - What is wrong with it and how to fix it, ECPR Press. 1380.

Granovetter, M. (1973) 'The Strength of Weak Ties', American Journal of Sociology, 78(6):1360-

Greenwood, R., Suddaby, R., and Hinings, C. R. (2002) 'Theorizing change: the role of professional associations in the transformation of institutionalized fields', Academy of Management Journal, 45(1):5880 .

Haas, P. (1992) 'Introduction: Epistemic Communities and International Policy Coordination', International Organization, 46(1): 1-35.

Hall, P. and Soskice, D. (eds.) (2001) 'Varieties of Capitalism: The Institutional Foundations of Comparative Advantage', Oxford University Press.

Hammersley, M. and Atkinson, P. (2007) 'Ethnography: Principles in Practice', 3Rev Ed edition. London, New York: Routledge.

Hampton, M. and Christensen, J. (2011) 'Looking for Plan B: What Next for Island Hosts of Offshore Finance?', The Round Table, 100(413):169-181.

Harrington, B. (2012) 'Trust and Estate Planning: The Emergence of a Profession and Its Contribution to Socioeconomic Inequality', Sociological Forum, 27(4):825-846.

Hearson, M. (2014) [blog post] 'What is the UN tax committee for, anyway?', 29 May 2014, <https://martinhearson.wordpress.com/2014/05/29/what-is-the-un-tax-committee-for-anyway/>; (accessed 24 July 2015) 
Hearson, M. and Christensen, J. (2011) [blog post] 'The OECD does not have all the answers', 1 November 2011, <http://www.taxresearch.org.uk/Blog/2011/11/01/oecd-should-step-aside-and-let-untackle-tax-havens-say-tax-justice-network-and-action-aid/>; (accessed 24 July 2015)

Herzfeld, M, (2014) [blog post] 'International Tax Trending', 20 June 2014, <http://www.taxanalysts.com/taxcom/taxblog.nsf/Permalink/UBEN-9L9FHH?OpenDocument>; (accessed 24 July 2015)

Hudson, A. (2000) 'Offshoreness, Globalization and Sovereignty: A Postmodern GeoPolitical Economy?', Transactions of the Institute of British Geographers: New Series, 25(3):269283.

IPB (2014) 'Comment letter on discussion draft on transfer pricing documentation and $C b C$ Reporting', <http://www.oecd.org/tax/transfer-pricing/comments-discussion-draft-transfer-pricingdocumentation.htm>; (accessed 24 July 2015)

Johnston, S. (2013) 'Come Together: A Look at the OECD’s Working Parties', Tax Notes International, 72(4).

Keck, M. and Sikkink, K. (1998) Activists beyond Borders: Advocacy Networks in International Politics. Ithaca: Cornell.

Lall, R. (2012) 'From failure to failure: The politics of international banking regulation', Review of International Political Economy, 19(4):609-638.

MacIndoe, H., and Abbott, A. (2004) 'Sequence Analysis and Optimal Matching Techniques for Social Science Data' in Hardy, M., and Bryman, A. (eds) Handbook of Data Analysis, Thousand Oaks, CA: Sage, pp. 387-406.

Mattli, W., and Büthe, T. (2011) The New Global Rulers: The Privatization of Regulation in the World Economy, Princeton: Princeton University Press.

Morriss, A. P., and Moberg, L. (2012) 'Cartelizing Taxes: Understanding the OECD’s Campaign against "Harmful Tax Competition", Columbia Journal of Tax Law, 4(1).

Muzio, D., Brock, D.M., Suddaby, R. (2013) 'Professions and Institutional Change: Towards an Institutionalist Sociology of the Professions: Professions and Institutional Change'. Journal of Management Studies 50, 699-721.

Nolan, A, (2014) 'A small country perspective on international taxation', presentation at Oxford University Centre for Business Taxation Summer Conference, 23 June 2014, <http://www.finance.gov.ie/sites/default/files/Ann\%20Nolan\%20Presentation\%20for\%200xford\%20Uni versity\%20.pdf $>$; (accessed 24 July 2015)

OECD Insights (2012) 'Price fixing', <http://oecdinsights.org/2012/03/26/price-fixing/>; (accessed 24 July 2015)

OECD Taleo (2015) 'OECD Job Openings',

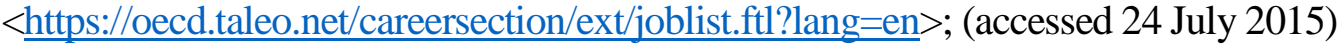

OECD (2013) 'Action Plan on Base Erosion and Profit Shifting', <http://dx.doi.org/10.1787/9789264202719-en>; (accessed 24 July 2015) 
OECD (2014a) 'Discussion draft on transfer pricing documentation and CbC reporting', <http://www.oecd.org/ctp/transfer-pricing/discussion-draft-transfer-pricing-documentation.pdf>; (accessed 24 July 2015)

OECD (2014b) 'Guidance on Transfer Pricing Documentation and Country-by-Country Reporting -Action 13: 2014 Deliverable', <http://www.oecd-ilibrary.org/taxation/guidance-on-transfer-pricingdocumentation-and-country-by-country-reporting 9789264219236-en>; (accessed 24 July 2015)

OECD (2015a) 'Action 13: Guidance on the Implementation of Transfer Pricing Documentation and Country-by-Country Reporting', <http://www.oecd.org/ctp/beps-action-13-guidance-implementationtp-documentation-cbc-reporting.pdf > ; (accessed 24 July 2015)

OECD (2015b) 'Action 13: Country-by-Country Reporting Implementation Package', $<$ http://www.oecd.org/ctp/transfer-pricing/oecd-releases-implementation-package-for-beps-country-bycountry-reporting.htm>; (accessed 24 July 2015)

Pagliari, S., and Young, K. (2014) 'The Interest Ecology of Financial Regulation: Interest Group Diversity and Conflict in the Design of Financial Regulatory Policies'. Paper presented at International Studies Association Annual Conference 2014.

Palan, R. (2003) The Offshore World, New York: Cornell University Press

Palan, R., Murphy, R. and Chavagneux, C. (2010) Tax Havens: How Globalization Really Works, New York: Cornell University Press.

Palan, R., and Wigan, D. (2014) 'Herding Cats and Taming Tax Havens: The US Strategy of 'Not In My Backyard”, Global Policy, 5(3):334-343.

Picciotto, S. (1995) 'The construction of international taxation. In Dezalay, Y., and Sugarman, D. (eds.). Professional Competition and Professional Power, pp. 17-35. London: Routledge.

Picciotto, S. (2015) 'Indeterminacy, complexity, technocracy and the taxation of transnational corporations', Social and Legal Studies, 24(2).

Porter, T., and Webb, M. (2007) 'The Role of the OECD in the Orchestration of Global Knowledge Networks', paper for presentation at Canadian Political Science Association, 30 May 2007, <http://www.cpsa-acsp.ca/papers-2007/Porter-Webb.pdf>; (accessed 24 July 2015)

PwC (2013) 'Tax transparency and country-by-country reporting: An ever changing landscape', $<$ https://www.pwc.com/en_GX/gx/tax/publications/assets/pwc_tax_transparency_andcountry_by_country_reporting.pdf $>$; (accessed 24 July 2015)

Quack, S. (2007) 'Legal Professionals and Transnational Law-Making: A Case of Distributed Agency’, Organization, 14(5):643-666.

Quentin, D. (2014) Risk-Mining the Public Exchequer, <http://www.davidquentin.co.uk/RiskMining The Public Exchequer.pdf>; (accessed 21 February 2016)

Rixen, T. (2010) 'From double tax avoidance to tax competition: Explaining the institutional trajectory of international tax governance', Review of International Political Economy, 18(2):197-227.

Rixen, T. (2013) 'Why reregulation after the crisis is feeble: Shadow banking, offshore financial centers, and jurisdictional competition', Regulation \& Governance, 7(4):435-459. 
Salzman, J. (2005) 'Decentralized Administrative Law in the Organization for Economic Cooperation and Development', Law and Contemporary Problems, 68:189-224.

Seabrooke, L. (2014) 'Epistemic arbitrage: Transnational professional knowledge in action', Journal of Professions and Organization, 1:49-64.

Seabrooke, L. and Nilsson, E.R. (2015) 'Professional Skills in International Financial Surveillance: Assessing Change in IMF Policy Teams', Governance: An International Journal of Policy, Administration and Institutions, 28(2):237-254

Seabrooke, L., and Sending, O. J. (2014) 'Open Systems of International Organization', Draft paper for AGORA V, University of Warwick, 7-8 October 2014.

Seabrooke, L. and Tsingou, E. (2009) 'Revolving Doors and Linked Ecologies in the World Economy: Policy Locations and the Practice of International Financial Reform', University of Warwick CSGR Working Paper, No. 260/09

Seabrooke, L. and Tsingou, E. (2014) 'Distinctions, affiliations, and professional knowledge in financial reform expert groups', Journal of European Public Policy, 21(3):389-407.

Seabrooke, L. and Tsingou, E. (2015) 'Revolving Doors in International Financial Governance', [unpublished].

Seabrooke, L., and Wigan, D. (2013) 'Emergent Entrepreneurs in Transnational Advocacy Networks: Professional Mobilization in the Fight for Global Tax Justice', GR:EEN Working Paper No. 41, Centre for the Study of Globalisation and Regionalisation, University of Warwick, <www.greenfp7.eu/papers/workingpapers>; (accessed 24 July 2015)

Seabrooke, L. and Wigan, D. (2014) 'The Governance of Global Wealth Chains', NUPI Working Paper 839, Norwegian Institute of International Affairs.

Seabrooke, L. and Wigan, D. (2017) 'The Governance of Global Wealth Chains', Review of International Political Economy 24 (1): 1-29.

Sending, O. J. (2002) 'Constitution, Choice and Change: Problems with the 'Logic of Appropriateness' and its Use in Constructivist Theory', European Journal of International Relations, 8(4):443-470.

Sharman, J. C (2009) 'The bark is the bite: International organizations and blacklisting', Review of International Political Economy, 16(4):573-596

Sharman, J. C. (2012) 'Seeing Like the OECD on Tax’, New Political Economy, 17(1):17-33.

Sikka, P., and Willmott, H. (2010) 'The Dark Side of Transfer Pricing: Its Role in Tax Avoidance and Wealth Retentiveness', Critical Perspectives on Accounting, 21(4):342-356.

Slemrod, J. (2006) 'Taxation and Big Brother: Information, Personalization, and Privacy in 21st Century Tax Policy', University of Michigan Ross School of Business Working Paper Series, No. 1022.

Suddaby, R., and Viale, T. (2011) 'Professionals and field-level change: Institutional work and the professional project', Current Sociology, 59(4):423-442. 
Tomaskovic-Devey, A., Carpenter, R. C. and Brownlie, K. (2011) 'Agenda-Setting in Transnational Networks: Findings from Consultations with Human Security Practitioners', <http://people.umass.edu/charli/networks/CPPA_Report.pdf>; (accessed 24 July 2015)

Trubek, D. M., Dezalay, Y., Buchanan, R., \& Davis, J. R. (1994) 'Global Restructuring and the Law: Studies of the Internationalization of Legal Fields and the Creation of Transnational Arenas', Case Western Reserve Law Review, 44(2):407-98. 85(4).

Tsingou, E. (2014) 'The Club Rules in Global Financial Governance', The Political Quarterly,

Vega, A. (2012) 'International governance through soft law: The case of the OECD transfer pricing guidelines', TranState Working Papers, No. 163.

Wedel, J. (2009) Shadow Elite: How the World's New Power Brokers Undermine Democracy, Government and The Free Market, Philadelphia: Basic Books.

Webb, M. (2004) 'Defining the boundaries of legitimate state practice: norms, transnational actors and the OECD's project on harmful tax competition', Review of International Political Economy, 11(4):787-827.

Woodward, R. (2009) The organisation for economic cooperation and development (OECD), Routledge Global Institutions Series, Volume 35. Oxford:Routledge.

Young, K. (2012) 'Transnational regulatory capture? An empirical examination of the transnational lobbying of the Basel Committee on Banking Supervision', Review of International Political Economy, 11(4):663-688. 


\section{Appendix}

Substitution cost matrix

\begin{tabular}{|l|l|l|l|l|l|l|l|l|l|l|l|l|l|l|l|l|l|l|}
\hline & $*$ & ACA & ACIO & ACPR & ACS & ECIO & ECPR & ECS & MNIO & MNPR & MNPU & OTH & TLIO & TLPR & TLS & TPIO & TPPR & TPS \\
\hline$*$ & 0 & 2 & 2 & 2 & 2 & 2 & 2 & 2 & 2 & 2 & 2 & 2 & 2 & 2 & 2 & 2 & 2 & 2 \\
\hline ACA & 2 & 0 & 3 & 3 & 3 & 3 & 3 & 3 & 3 & 3 & 3 & 3 & 3 & 3 & 3 & 3 & 3 & 3 \\
\hline ACIO & 2 & 3 & 0 & 1 & 1 & 3 & 3 & 3 & 2 & 3 & 3 & 3 & 3 & 3 & 3 & 2 & 2 & 2 \\
\hline ACPR & 2 & 3 & 1 & 0 & 1 & 3 & 3 & 3 & 3 & 2 & 3 & 3 & 3 & 3 & 3 & 2 & 2 & 2 \\
\hline ACS & 2 & 3 & 1 & 1 & 0 & 3 & 3 & 3 & 3 & 3 & 2 & 3 & 3 & 3 & 3 & 2 & 2 & 2 \\
\hline ECIO & 2 & 3 & 3 & 3 & 3 & 0 & 1 & 1 & 2 & 3 & 3 & 3 & 3 & 3 & 3 & 2 & 2 & 2 \\
\hline ECPR & 2 & 3 & 3 & 3 & 3 & 1 & 0 & 1 & 3 & 2 & 3 & 3 & 3 & 3 & 3 & 2 & 2 & 2 \\
\hline ECS & 2 & 3 & 3 & 3 & 3 & 1 & 1 & 0 & 3 & 3 & 2 & 3 & 3 & 3 & 3 & 2 & 2 & 2 \\
\hline MNIO & 2 & 3 & 2 & 3 & 3 & 2 & 3 & 3 & 0 & 1 & 1 & 3 & 2 & 3 & 3 & 2 & 3 & 3 \\
\hline MNPR & 2 & 3 & 3 & 2 & 3 & 3 & 2 & 3 & 1 & 0 & 1 & 3 & 3 & 2 & 3 & 3 & 2 & 3 \\
\hline MNPU & 2 & 3 & 3 & 3 & 2 & 3 & 3 & 2 & 1 & 1 & 0 & 3 & 3 & 3 & 2 & 3 & 3 & 2 \\
\hline OTH & 2 & 3 & 3 & 3 & 3 & 3 & 3 & 3 & 3 & 3 & 3 & 0 & 3 & 3 & 3 & 3 & 3 & 3 \\
\hline TLIO & 2 & 3 & 3 & 3 & 3 & 3 & 3 & 3 & 2 & 3 & 3 & 3 & 0 & 1 & 1 & 2 & 2 & 2 \\
\hline TLPR & 2 & 3 & 3 & 3 & 3 & 3 & 3 & 3 & 3 & 2 & 3 & 3 & 1 & 0 & 1 & 2 & 2 & 2 \\
\hline TLS & 2 & 3 & 3 & 3 & 3 & 3 & 3 & 3 & 3 & 3 & 2 & 3 & 1 & 1 & 0 & 2 & 2 & 2 \\
\hline TPIO & 2 & 3 & 2 & 2 & 2 & 2 & 2 & 2 & 2 & 3 & 3 & 3 & 2 & 2 & 2 & 0 & 1 & 1 \\
\hline TPPR & 2 & 3 & 2 & 2 & 2 & 2 & 2 & 2 & 3 & 2 & 3 & 3 & 2 & 2 & 2 & 1 & 0 & 1 \\
\hline TPS & 2 & 3 & 2 & 2 & 2 & 2 & 2 & 2 & 3 & 3 & 2 & 3 & 2 & 2 & 2 & 1 & 1 & 0 \\
\hline
\end{tabular}

